\title{
Use of higher-protein diets during intense military training to decrease lean tissue loss and improve performance
}

\author{
Jennifer A Case ${ }^{1 *}$, Mark D Haub ${ }^{1}$, Allison Teeter ${ }^{2}$, Kelcie Hubach ${ }^{1}$ \\ From International Society of Sports Nutrition: 7th Annual ISSN Conference and Expo \\ Clearwater Beach, FL, USA. 24-26 June 2010
}

\section{Background}

Current dietary intakes of active military personnel during intense training sessions may result in loss of lean tissue mass due to lower intake of energy and protein. It was hypothesized that a higher-protein diet (HPD) with frequent meals would result in greater lean tissue maintenance and improved performance during intense military training.

\section{Design}

36 Air Force cadets completed a 12-day training session. A HPD (40\% carbohydrate, 30\% protein, 30\% fat) with frequent meals was prescribed to each participant. Cadets completed 4 hours of supervised exercise daily. Pre- and post-test assessments included: body weight, body composition, vertical jump height, leg power index (LPI) and anaerobic testing.

\section{Results}

A negative correlation was found between the change in average vertical jump height and protein intake. Total body mass increased by $0.6 \pm 1.1 \mathrm{~kg}(\mathrm{p}<.001)$, and percent body fat decreased by $1.1 \pm 0.9(\mathrm{p}<.001)$. Fat-free mass increased by $1.3 \pm 1.1 \mathrm{~kg}(\mathrm{p}<.001)$, fat-mass decreased by $0.7 \pm 0.7(\mathrm{p}<.001)$. Averaged 600 meter times decreased by $1.2 \pm 1.8$ seconds ( $<<.001)$. Peak LPI (LPI) and average LPI increased by $0.12 \pm 0.22$ ( $\mathrm{p}<.001)$ and $0.13 \pm 0.22(\mathrm{p}<.001)$, respectively. Total energy intake was $14,110 \pm 4,389 \mathrm{~kJ}$. Macronutrient breakdown of diets was $52 \pm 11 \%$ carbohydrates (437 $\pm 155 \mathrm{~g}), 19 \pm$ $4 \%$ protein $(157 \pm 65 \mathrm{~g})$ and $32 \pm 9 \%$ fat $(119 \pm 53 \mathrm{~g})$. There was no correlation between meal frequency and anthropometric changes or performance changes. Meal frequency consisted of $64 \%$ of the subjects consuming 3 meals and 1 to 3 snacks daily, 22\% of the subjects only consumed 2 meals and 1 to 3 snacks daily, and $13 \%$ of participants reported consuming 2 large meals and no snacks daily.

\section{Conclusion}

Frequent meals and snacking appears to have resulted in maintenance and an increase in fat-free mass. The increase in LPI may be partially due to the increase in FFM. However, due to lack of dietary adherence, the hypothesis of this study could not be tested accurately.

\section{Acknowledgements}

Thank you to Dave Durnil and James Lattimer for their assistance during data collection, and to Kristin Hodges for a critical reading of the manuscript.

\section{Author details}

${ }^{1}$ Department of Human Nutrition, Kansas State University, 212 Justin Hall, Manhattan, KS 66506, USA. ²Department of Sociology, Anthropology, and Social Work, Kansas State University, 204 Waters Hall, Manhattan KS 66506, USA

Published: 15 September 2010

\section{doi:10.1186/1550-2783-7-S1-P5}

Cite this article as: Case et al:: Use of higher-protein diets during intense military training to decrease lean tissue loss and improve performance. Journal of the International Society of Sports Nutrition 2010 7(Suppl 1):P5. 